\title{
Influence of feeding regime and finishing system on lamb muscle fiber and meat quality ${ }^{1}$
}

\section{Sarita Bonagurio Gallo², Edson Ramos de Siqueira ${ }^{3}$, Eduardo Francisquine Delgado ${ }^{4}$, Maeli Dal Pai Silva ${ }^{5}$, Gilberto Teixeira da Rosa ${ }^{6}$}

1 Pesquisa financiada pela FAPESP.

2 Faculdades Associadas de Uberaba - FAZU, Uberaba, MG.

${ }^{3}$ Departamento de Produção Animal da Faculdade de Medicina Veterinária e Zootecnia - FMVZ/UNESP, Campus de Botucatu, SP.

${ }^{4}$ ESALQ - USP - Piracicaba, SP.

5 Instituto de Biociência da UNESP, Botucatu, SP.

${ }^{6}$ In memoriam.

ABSTRACT - The study verified the influence of different nutritional levels of the dams, before parturition, the weaning age of the lambs and the finishing system on lamb muscle fiber morphology and meat quality. Ile-de-France $\times$ Bergamacia crossbred dams grazing on natural grassland were divided into two groups: 1) nutritional supplement 30 days before the parturition (SUPL), and 2) no nutritional supplement (NS). These groups were further subdivided by weaning age of the lambs, which corresponded to either 45 or 60 days. The weaned lambs from each of the previous groups were also divided into different finishing systems: confined and fed a complete diet (CD), confined and fed hay $(\mathrm{H})$ and kept on grassland (P). The lambs were slaughtered at $30 \mathrm{~kg}$ live weight $(\mathrm{CD}$ and $\mathrm{P})$, or at 150 days of age $(\mathrm{H})$. The carcasses were cooled at $4^{\circ} \mathrm{C} / 24 \mathrm{~h}$. The analyzed variables were: longissimus dorsi muscle fiber morphophysiology, post mortem myofibrillar fragmentation (at 0,3 and 7 days post mortem), meat $\mathrm{pH}$ and temperature. There was no effect of supplementation of dams or weaning age of the lambs for the evaluated variables. The frequency of slow-oxidative (SO), fast-oxidative-glycolytic (FOG) and fast-glycolytic (FG) muscle fiber types was not altered by the treatments, but the fiber cross-sectional area was smaller for the lambs finished only on hay, and the meat $\mathrm{pH}$ values and temperature were lower and the myofibrill fragment dimensions were smaller. As time maturation increased from 0 to 3 and 7 days post mortem, there was a decrease in the length of the myofibrill fragments. The diet of the lambs which were maintained confined and fed only with hay was nutritionally inferior when compared with all the others, and this changed the quality of the meat compared to the finishing systems on grassland or confined and fed complete diet.

Key Words: muscle fiber type, myofibrill, morphology, $\mathrm{pH}$, temperature

\section{Influência do regime alimentar e do sistema de terminação sobre as fibras musculares e a qualidade da carne de cordeiros}

\footnotetext{
RESUMO - Avaliou-se a influência dos níveis nutricionais da ovelha antes do parto, da idade à desmama e do sistema de terminação sobre as fibras musculares e a qualidade da carne dos cordeiros. Utilizaram-se matrizes mestiças Ile de France $\times$ Bergamacia criadas a pasto. As ovelhas foram divididas em dois grupos: um com suplementação alimentar 30 dias antes do parto e outro sem suplementação. Os animais (ovelha e cordeiros) foram subdivididos de acordo com a idade à desmama (45 ou 60 dias de idade) e os cordeiros desmamados foram submetidos a três sistemas de terminação: confinamento com dieta completa; confinamento somente com feno; e confinamento somente no pasto. O abate dos cordeiros foi realizado aos $30 \mathrm{~kg}$ de peso vivo ou aos 150 dias de idade. As características de carcaça analisadas foram morfofisiologia da fibra do músculo longissimus dorsi, fragmentação miofibrilar pós-morte (maturados nos dias 0, 3 e 7 pos mortem) e redução do pH e da temperatura da carne pós-abate. Não houve efeito da suplementação às ovelhas ou da idade à desmama sobre nenhuma das características avaliadas. A composição em fibras de contração lenta e oxidativa, contração rápida e oxidativa ou contração rápida e glicolítica não foi alterada pelos fatores em estudo, mas a área transversal das fibras foi menor nos cordeiros terminados com feno, assim como os valores de $\mathrm{pH}$, temperatura e as medidas dos fragmentos de miofibrila. Com o aumento do tempo de maturação de 0 para 3 e 7 dias post mortem, houve redução do comprimento dos fragmentos de miofibrilas. O sistema de terminação de cordeiros em confinamento somente com feno interfere mais intensamente na qualidade da carne que o sistema de terminação a pasto ou em confinamento com dieta completa.
}

Palavras-chave: miofibrila, morfologia, $\mathrm{pH}$, temperatura, tipo de fibra muscular 


\section{Introduction}

Ruminants, due to their characteristic digestive system, obtain nutrients from fibrous feeds, such as roughage (Van Soest, 1994), which is an advantage to the producer, since the finishing phase on pastures is less labor intensive compared to feedlots and also presents lower fixed costs in building maintenance. However, a major problem in animals kept on pastures is nutritional deficiency, where they certainly experience great variability in protein, energy and fiber content in the forage during a year (dry and rainy season). In the feedlot, this problem is solved because there is consistency in feed quality and quantity offered and parasite infestation much lower than in pastures.

Severe malnutrition of ewes during gestation may decrease the number of myofibers in the fetuses and harm their growth and performance after birth (Greenwood et al., 2000). On the other hand, moderate malnutrition of ewes during early pregnancy did not affect muscle development of the offsprings and the myofiber number, and therefore there is a growing interest in studying feed restriction during pregnancy (Greenwood et al., 2000). In the finishing systems, lambs under restricted feeding presented myofiber atrophy and slower post mortem $\mathrm{pH}$ drop in the muscle (Lefaucherur \& Gerrard, 1998), which altered meat quality.

It has been shown that sheep meat tenderization may be altered by the growth rate dictated by feed restriction (McDonagh et al., 1999). These changes in the protein degradation system involved in meat tenderization post mortem due to growth rate modified the myofibrillar fragmentation process, as reported for different feed regimens including feed restriction and compensatory growth in another animal model (Leonardo et al., 2008). The myofibrillar fragmentation index is one of best biochemical markers of red meat tenderness (Whipple et al., 1990).

The objective of this study was to evaluate the consequences of prepartum food supplementation of ewes, weaning age of the offsprings and the finishing system of the lambs on the myofiber type and size and meat quality attributes.

\section{Material and Methods}

The first part of the experiment was conducted on the Palmeira da Serra farm, Pratânia-SP, and the feedlot for the lambs was located at the sheep facilities at the Faculdade de Medicina Veterinária e Zootecnia at UNESP, on the Botucatu campus in São Paulo state. Ile-de-France $\times$ Bergamacia cross-bred ewes were mated with Ile-de-France rams, and fifty-four ewes that delivered male lambs were used in this study.

The dams were maintained on pastures of Panicum maximum, cv. Tanzânia, in a rotational grazing system and separated into two groups. The paddocks, measuring approximately one hectare, were kept on 7-day grazing and 35 -day rest periods. Group $1(\mathrm{n}=27)$ was formed by ewes that received a supplementation of $500 \mathrm{~g} /$ head.day of a commercial feed for 30 days prior to parturition, while group 2 consisted of the ewes $(n=27)$ that did not receive any supplementation. The probable parturition date was obtained by controlling the mount. The ewes had free access to mineral mixture throughout the experiment.

The groups of ewes were further subdivided according to weaning age of the lambs ( 45 and 60 days of age). The group of ewes receiving supplementation with lambs weaned at 45 days had 12 animals, and with lambs weaned at 60 days, 15 animals. The group without supplementation with lambs weaned at 45 days consisted of 14 animals, while 13 of the ewes in that group had their lambs weaned at 60 days of age. The lambs weaned at 45 days had an average live weight of $18 \mathrm{~kg}$, while the average live weight of lambs weaned at 60 days was $23 \mathrm{~kg}$.

After weaning, the lambs were distributed in three finishing systems: feedlot lambs fed complete diet (22 lambs), according to NRC (1985); feedlot lambs fed exclusively a grass hay-based diet (21 lambs); grazing lambs with supplementation (11 lambs). The slaughter weight established was $30 \mathrm{~kg}$ for feedlot lambs fed complete diet and grazing lambs or 150 days of age for feedlot lambs fed a grass hay-based diet.

The complete diet offered to the lambs in the feedlot consisted of a commercial feed ( finishing sheep diet from Vitosan, Ministry of Agriculture registration $\mathrm{n}^{\circ} \mathrm{RS} 01008$ 00051) and Aruana-grass hay (roughly chopped), in a roughage to concentrate ratio of 70:30 for weight gain of $300 \mathrm{~g}$ /day according to NRC (1985). The aruana-grass hay was offered ad libitum and unchopped for feedlot lambs fed only roughage. The grazing lambs were kept in one hectare paddocks composed of Panicum maximum, cv. Tanzânia, in a 7 days grazing and 35 days rest rotational grazing system with $200 \mathrm{~g} /$ head.day supplementation (commercial feed used by the farm).

The nutritional value of the pasture varied during experimental period and the values shown are an average of the determinations obtained during the experiment. The forage collected was analyzed as a whole, without separating leaves from stalks. The bromatological composition analysis of the commercial feed confirmed manufacturer information and the nutritional values 
obtained for hay and forage from pasture were obtained by analysis according to procedures adopted in the Laboratório de Nutrição at the Departamento de Melhoramento e Nutrição Animal of FMVZ - UNESP Botucatu (Table 1).

Either after reaching $30 \mathrm{~kg}$ or 150 days of age, the lambs were submitted to a 16-hour fast and immediately slaughtered. The carcasses were refrigerated in a cold room for 24 hours at $4 \pm 2{ }^{\circ} \mathrm{C}$. Samples from the longissimus dorsi muscle were taken for the morphological analysis of myofiber, meat $\mathrm{pH}$ and temperature and, myofibril fragment dimensions. The fat thickness and ribeye area were determined at the $12-13^{\text {th }}$ ribs.

Samples for morphological measurements of myofibers were taken immediately after slaughter, at sizes of approximately $1 \mathrm{~cm} \times 0.5 \mathrm{~cm}$, covered by neutral powder and frozen in liquid nitrogen; they were transported to the Laboratório de Histoenzimologia, Departamento de Morfologia, at the Instituto de Biociências da Unesp, Botucatu, and stored at $-80^{\circ} \mathrm{C}$. Ten mm wide samples were cut on a cryostat. The slides were prepared by the hematoxilin-eosin technique for general evaluation of muscle morphology. The samples were fixed with Baker formaldehyde calcium, stained with hematoxilin-eosin, alcohol and xylol. For ATPase analysis, several $\mathrm{pH}$ values $(4.1 ; 4.5 ; 4.6 ; 10.4,10.5 ; 10.6)$ were tested. We utilized $\mathrm{pH}$ of 10.65, which allowed differentiation of the three types of fiber, classified as bright, black, and gray, as described by Macedo (2000). The samples were kept in pre-incubation solution (Sigma 221 buffer, $0.18 \mathrm{M}$ calcium chloride and deionazed water, $\mathrm{pH}$ 10.65), followed by an incubation solution (Sigma 221 buffer, $0.18 \mathrm{M}$ calcium chloride, ATP e deionazed water), $1 \%$ calcium chloride, $2 \%$ cobalt chloride and ammonium sulfate. The morphometric analyses were made at the Departamento de Histoenzimologia, at the Instituto de Biociências da Unesp.

Table 1 - Nutritional composition, in percentage, of the feed available in the finishing systems

\begin{tabular}{lccr}
\hline Item & Commercial ration & Hay & Pasture \\
\hline Dry matter & 87 & 88.67 & 90.20 \\
Crude protein & 18 & 11.42 & 5.29 \\
Crude fiber & 17 & 41.86 & 34.02 \\
Mineral & 10 & 9.77 & 8.48 \\
Neutral detergent fiber & & 75.24 & 74.34 \\
Acid detergent fiber & & 55.62 & 50.60 \\
Total digestible nutrients & $64.05^{*}$ & $48.45^{* *}$ & $50.73^{* *}$ \\
Calcium & 2 & & \\
Phosphorus & 0,4 & & \\
\hline
\end{tabular}

$*$ TDN calculated $=40.32+(0.5398 \times \mathrm{CP})+(0.4448 \times \mathrm{NNE})+(1.422 \times \mathrm{EE})-$ $(0.7007 \times \mathrm{CF})$

** TDN calculated $=17.26+(1.212 \times \mathrm{CP})+(0.8352 \times \mathrm{NNE})+(2.464 \times \mathrm{EE})+$ $(0.4475 \times \mathrm{CF})$
The muscle fibers were assessed in an optical microscope with 40x magnification, coupled to an image analyzer (Vídeoplan Optimas, USA) at DMNA, FMVZ, Unesp. One hundred and eleven measurements were used per animal as an average of readings for hematoxilin-eosin; for ATPase, an average of 314 measures/animal; measurements were taken in a total of 52 animals.

The $\mathrm{pH}$ and temperature measurements were taken from the longissimus dorsi muscle at $0,4,8,12$ and 24 hours post mortem, using a 0.01 resolution portable $\mathrm{pH}$ meter equipped with a penetration electrode.

The ribeye area was obtained after a transversal cut of the carcass at the 12-13th rib to expose the longissimus dorsi muscle. Butter paper was used to trace the surroundings of the muscle, which afterwards was taken to an electronic table to have the enclosed area measured by a planimeter. Fat thickness was obtained by measurements taken by a pachimeter over the center of the ribeye muscle.

The samples for the myofibril fragment measurements were obtained on slaughter day (day 0 ) and at 3 and 7 days of maturation. The maturation occurred in vaccum packed meat stored at $4{ }^{\circ} \mathrm{C}$. The fragmentation was performed by homogenizing samples in buffer solution $(100 \mathrm{mM} \mathrm{KCl}$, $20 \mathrm{mM}$ monobasic and dibasic potassium phosphate, $1 \mathrm{mM}$ EDTA, $1 \mathrm{mM} \mathrm{MgCl} 2 \cdot 6 \mathrm{H}_{2} \mathrm{O}$ and $1 \mathrm{mM} \mathrm{NaN}_{3}, \mathrm{pH}$ 7.0 at $4{ }^{\circ} \mathrm{C}$ ). The samples were standardized to a final protein concentration of $0.1 \mathrm{mg} / \mathrm{mL}$ and loaded into a Newbauwer chamber. The slides were observed under an optical microscope coupled to an image analyzer (Axion Vision - Carl Zeiss). A 20x lens was used to obtain the measurements of an average of 38 myofibril fragments per animal, totaling observation of three lambs per treatment.

A randomized complete design was used with a $2 \times 2 \times 3$ factorial arrangement, with two nutritional levels for ewes during the prepartum period, two weaning age of lambs (45 and 60 days) and three finishing systems (feedlot and complete diet or hay, or grazing). All data were analyzed by the GLM procedure of SAS (SAS, 1989). The weight at farm (animal weight without fasting) and slaughter age were used as covariates to the studied variables. The statistical analysis of measurements taken from the same animal and repeated in time and the myofibril fragments and myofiber frequency, meat $\mathrm{pH}$ and temperature were measured using a Split Plot arrangement, and the means were compared by the $t$ test at $1 \%$ of probability.

\section{Results and Discussion}

The feedlot lambs fed grass hay-based diet were slaughtered at the age end-point. These lambs were older 
$(\mathrm{P}<0.001)$ and presented lower live weight $(\mathrm{P}<0.001)$ than animals from the other finishing systems (Table 2). The lambs finished on pasture plus supplementation and those in feedlot on complete diet had similar slaughter age and live weight.

The factors studied (prepartum nutrition, weaning age, and lamb finishing system) did not influence $(\mathrm{P}<0.0979)$ the myofiber frequencies. The animals presented an expected myofiber type distribution, where a higher proportion of fast and glycolytic fiber (gray) was observed, followed by fast and oxidative fibers (dark), with lower percentage of slow and oxidative fibers (bright) (Table 3 ).

In general, the fibers presented a polygonal aspect with evident endomisium (Figure 1A). In the images prepared with hematoxilin-eosin, fiber atrophy was observed in the muscle of lambs fed exclusively on hay (Figure 1B), that may be related to nutritional deficiency that would indicate lower muscle protein accretion, which would result in poor performance of these animals compared to the other groups (Table 2).

The measurements of myofiber type areas, obtained by the alcaline ATPase technique, were affected $(\mathrm{P}<0.001$, Table 4) by the lamb finishing system. All fiber types were smaller in muscle from lambs fed on hay (Figure 2).

The prepartum maternal feed restriction did not influence the frequency and the myofiber size of the lambs, as previously described by Krausgril et al. (1999). There is a possibility of post-natal offspring recovery of the deficiency caused by maternal malnutrition (Du et al., 2004).

Another hypothesis would be that a dam develops ways to protect her fetus from imposed maternal feed restriction, to the point of her own muscle tissue loss to preserve normal fetus growth (Du et al., 2004).

The myofiber diameter and number as well as weight and size of lamb hindlimb muscles are probably not traits that can be changed by supplementation of dams during gestation, regardless of the period, as has been reported by Mexia et al. (2006) for the semitendinosus muscle of lambs raised on pasture with supplementation.

However, post-natal nutrition can alter the myofibers. The decreased fiber diameter is a muscle adaptation to some situations such as feed restriction (Macedo, $2000 \mathrm{a}, \mathrm{b}$ ). The diet based on hay was nutritionally limiting which resulted in lower weight gain and animal development. These animals were slaughtered at lower live weight $(25 \mathrm{~kg})$ and more advanced age (150 days) than lambs from the other

Table 3 - Frequency distribution of myofiber types in lamb longissimus dorsi, obtained by ATPase analysis

\begin{tabular}{lrc}
\hline Myofiber type* & Frequence (\%) & SEM \\
\hline Slow twitch and oxidative & $9.77 \mathrm{~A}$ & 0.96 \\
Fast twitch and oxidative & $35.01 \mathrm{~B}$ & 0.96 \\
Fast twitch and glycolytic & $55.21 \mathrm{C}$ & 0.96 \\
\hline
\end{tabular}

Means with different letters differ $(\mathrm{P}<0.01)$ by the $\mathrm{t}$ test.

Table 2 - Slaughter age and live weight of lambs finished in feedlot on complete diet or hay, or on pasture

\begin{tabular}{|c|c|c|c|c|}
\hline Finishing system & Slaughter age (days) & SEM & Slaughter live weight (kg) & SEM \\
\hline Feedlot/complete diet & $109.39 \mathrm{~A}$ & 2.89 & $32.48 \mathrm{~A}$ & 0.52 \\
\hline Feedlot/hay & $150.58 \mathrm{~B}$ & 3.05 & $25.37 \mathrm{~B}$ & 0.56 \\
\hline Pasture/supplementation & $119.58 \mathrm{~A}$ & 4.13 & $30.24 \mathrm{~A}$ & 0.75 \\
\hline
\end{tabular}

Means with different letters within the column differ $(\mathrm{P}<0.01)$ by the $\mathrm{t}$ test; $\mathrm{SEM}-$ standard error of the mean.

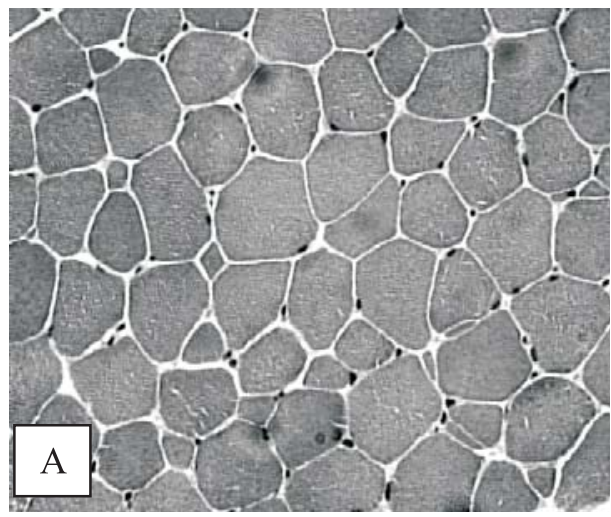

Images obtained with a 40x magnification lens.

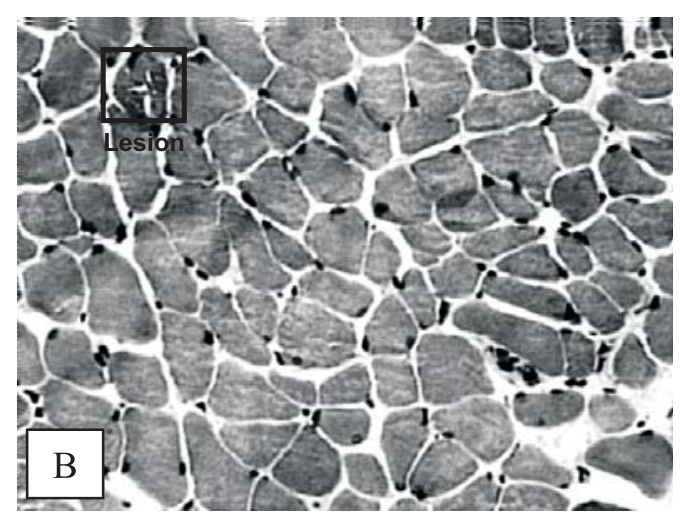

Figure 1 - Hematoxilin-eosin stained cross-section of longissimus dorsi muscle from lambs weaned at 60 days of age and finished in feedlot on complete $\operatorname{diet}(\mathrm{A})$ or on hay (B). 
finishing systems. This finishing system resulted in smaller myofibers, which may have weakened the muscle tissue resulting in the appearance of some lesions, as characterized at the atrophied muscle (Figure 1B).

There was no effect of finishing system in feedlot on complete diet and on pasture for frequency and myofiber size. The grassland had a flat topography and there was plenty of forage, especially in the rotational grazing system, which resulted in a similar growth rate on those systems, as reported by Macedo et al. (2000 a, b).

The $\mathrm{pH}$ and temperature $\left({ }^{\circ} \mathrm{C}\right)$ values of the longissumus dorsi muscle (Table 5) were not influenced $(\mathrm{P}>0.05)$ by the studied factors (prepartum nutrition, weaning age, and lamb finishing system). Slaughter age and weight were not significant covariables. The $\mathrm{pH}$ values varied from 6.9 immediately after slaughter to a final pH of 5.6 (24 hours post mortem). The average carcass temperature immediately after slaughter was $36^{\circ} \mathrm{C}$ and decreased to $7^{\circ} \mathrm{C}$ at 24 hours post mortem.
Krausgrill et al. (1999) did not show effect of feed restriction on meat $\mathrm{pH}$, but reported alterations in myofibers as a result of maternal nutrition differences. Even though there were no differences in meat $\mathrm{pH}$, lambs finished in feedlot and fed on hay presented smaller myofiber areas and also higher $\mathrm{pH}$ values (Table 5), with no differences between lambs of the other finishing systems, which are results similar to those reported by Velasco et al. (2004).

Lambs fed diet based on hay had smaller fat thickness (Table 6) and smaller muscle size, that may have contributed, at least partially, to a differentiated $\mathrm{pH}$ drop. The thin fat cover and smaller muscle size (ribeye area) leave carcass exposed to the low temperature of the cold room.

The lower muscle glycogen content of the lambs fed on hay that may be inferred by limited body reserves, could result in high final $\mathrm{pH}$ values (5.88), while the lambs from other finishing systems reached a final $\mathrm{pH}$ of 5.60, which corroborate data by Petrick \& Rowe (1996). According to reports by Immonen et al. (2000), McGeehim et al. (2001) and

Table 4 - Area of the myofiber types, obtained in hematoxilin-eosin stained and ATPase based classification, from muscle of lambs finished in feedlot on complete diet or hay, or on pasture

\begin{tabular}{lcccc}
\hline \multirow{2}{*}{ Item } & Hematoxilin-eosin & Slow twitch and oxidative & Fast twitch and oxidative & Fast twitch and glycolytic \\
\cline { 3 - 5 } & & \multicolumn{2}{c}{ Area $\left(\mu \mathrm{m}^{2}\right)$} & \\
Feedlot/complete diet & $948.10 \mathrm{~A}$ & $1142.77 \mathrm{Ax}$ & $755.37 \mathrm{Ay}$ & $1038.94 \mathrm{Ax}$ \\
Feedlot/hay & $643.40 \mathrm{~B}$ & $736.96 \mathrm{Bx}$ & $475.6 \mathrm{By}$ & $591.51 \mathrm{Bxy}$ \\
Pasture/supplementation & $963.80 \mathrm{~A}$ & $980.84 \mathrm{Axy}$ & $778.46 \mathrm{Ay}$ & $1123.85 \mathrm{Ax}$ \\
\hline
\end{tabular}

Means with distinct uppercase letters within a column or lowercase letters within a row $\operatorname{differ}(\mathrm{P}<0.01)$ by $\mathrm{t}$ test.
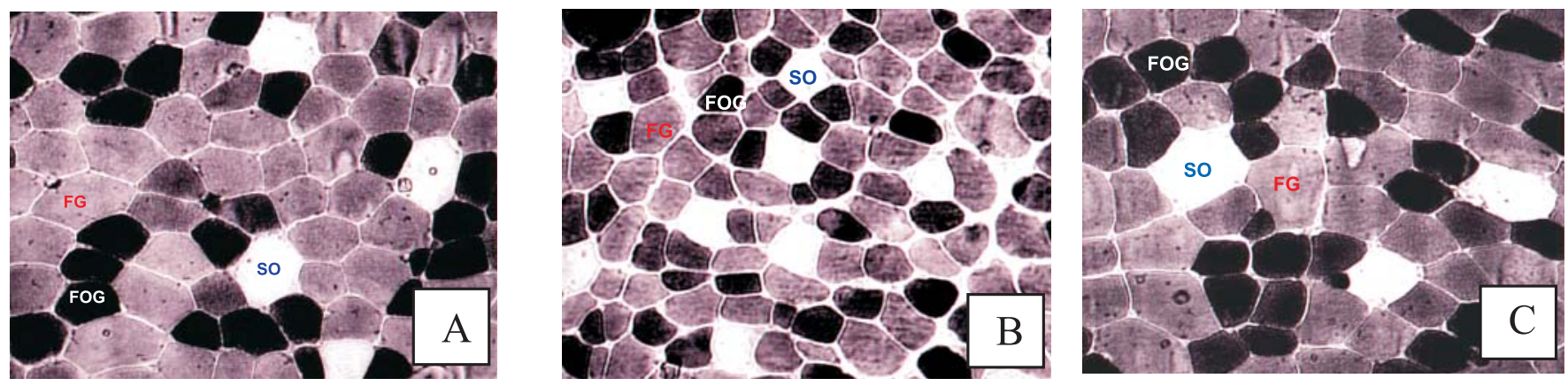

Figure 2 - The alcaline ATPase stain technique on cross-section of longissimus dorsi muscle from lambs finished in feedlot fed complete diet (A), in feedlot fed on hay (B) and finished on pasture (C). SO - Slow twitch and oxidative fiber type; FOG - Fast and oxidative fiber type; FG - Fast and oxidative fiber type.

Table 5 - Carcass $\mathrm{pH}$ and temperature of lambs finished in feedlot on complete diet or hay, or on pasture

\begin{tabular}{|c|c|c|c|c|c|}
\hline \multirow[b]{2}{*}{ Item } & \multicolumn{5}{|c|}{ Time post mortem (hours) } \\
\hline & 0 & 4 & 8 & 12 & 24 \\
\hline Feedlot/complete diet & $6.93 / 36^{\circ} \mathrm{C}$ & $6.49 / 10^{\circ} \mathrm{C}$ & $5.96 / 7{ }^{\circ} \mathrm{C}$ & $5.80 / 6{ }^{\circ} \mathrm{C}$ & $5.60 / 6{ }^{\circ} \mathrm{C}$ \\
\hline Feedlot/hay & $6.96 / 34{ }^{\circ} \mathrm{C}$ & $6.66 / 10^{\circ} \mathrm{C}$ & $6.18 / 7{ }^{\circ} \mathrm{C}$ & $6.02 / 7^{\circ} \mathrm{C}$ & $5.88 / 6{ }^{\circ} \mathrm{C}$ \\
\hline
\end{tabular}


Velasco et al. (2004), pH values are higher for animals presenting smaller fat thickness and residual glycogen concentration, which agree with the possible explanations for the results obtained for lambs fed on hay.

The length of myofibril fragments of the longissimus dorsi muscle did not differ among the lamb finishing systems or during meat maturation (Table 7), probably because of the high standard error and variation coefficient of the measurement (Figure 3).

Even though no differences were observed, the myofibril fragment length decreased with time of meat maturation.
The lambs fed on hay had smaller values for myofibril fragment length, which could be a result of smaller myofiber size verified in the muscles of these lambs. The degradation of myofibrillar proteins from bovine muscle increased with time of meat maturation, as described by Boehm et al. (1998), due to enzymatic action of the calpain. Therefore, the changes during meat maturation occur as a result of modifications in myofibrillar structure. The myofibril integrity varies only slightly immediately after slaughter, but in the meat maturation process, there is a fragilization which results in more tender meat.

Table 6 - Fat thickness and ribeye area from carcasses of lambs finished in feedlot on complete diet or hay, or on pasture

\begin{tabular}{lcccc}
\hline Finishing system & Fat thickness $(\mathrm{mm})$ & SEM & Ribeye $\operatorname{area}^{\left(\mathrm{cm}^{2}\right)}$ & $14.99 \mathrm{~A}$ \\
\hline Feedlot/complete diet & $1.69 \mathrm{~A}$ & 0.08 & $8.85 \mathrm{~B}$ & 0.79 \\
Feedlot/hay & $0.78 \mathrm{C}$ & 0.78 & $15.31 \mathrm{~A}$ & 0.83 \\
Pasture/supplementation & $1.25 \mathrm{~B}$ & 1.25 & 1.13 \\
\hline
\end{tabular}

Means with different letters within the column differ $(\mathrm{P}<0.01)$ by the $\mathrm{t}$ test; $\mathrm{SEM}-$ standard error of the mean.

Table 7 - Myofibril fragment length of the longissimus dorsi muscle of lambs finished in three systems (feedlot on complete diet or hay, or on pasture) and at different maturation times (days 0,3 and 7 pos mortem)

\begin{tabular}{ccc}
\hline & Myofibril & \\
\hline Feedragments length $(\mu \mathrm{m})$ & Pasture/Supplementation \\
$51.46 \pm 4.90$ & Feelot/hay & $54.63 \pm 4.10$ \\
Day 0 & $42.29 \pm 4.90$ & Day 7 \\
$54.97 \pm 4.28$ & Day 3 & $43.67 \pm 5.31$ \\
\hline
\end{tabular}

Means \pm SEM
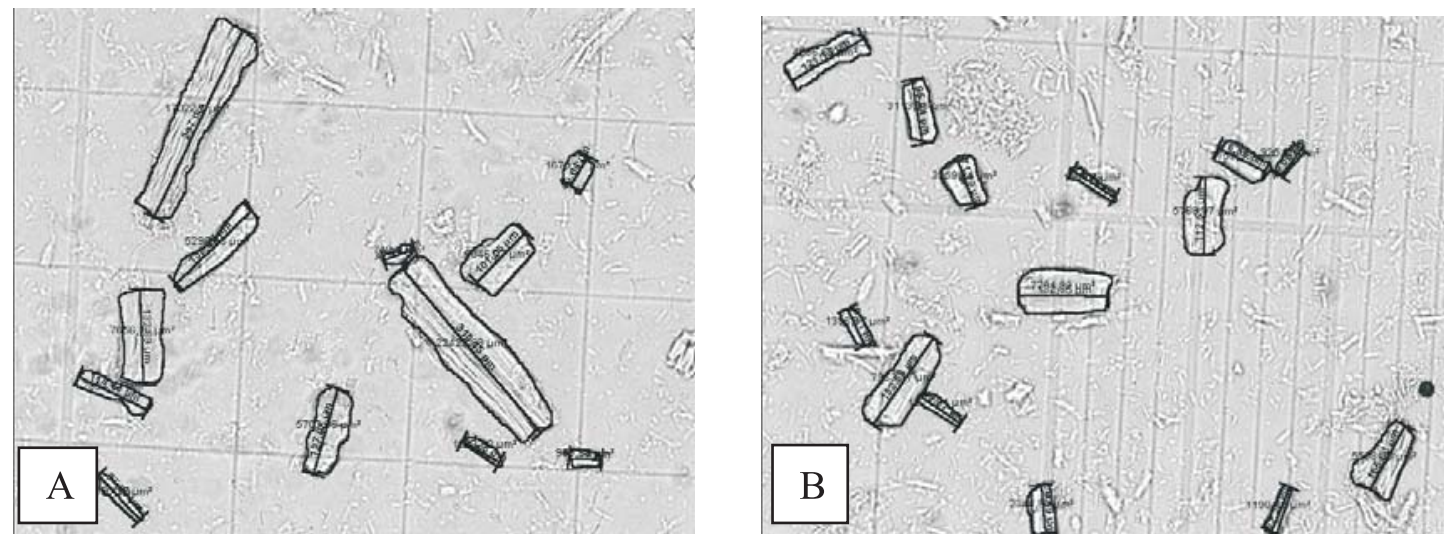

Figure 3 - Measurements of area and length of myofibril fragments $(\mu \mathrm{m})$ of the longissimus dorsi muscle taken from samples on slaughter day (A) and day 3 of meat maturation (B).

\section{Conclusions}

Lamb nutrition influenced myofiber morphology. The diet based exclusively on hay resulted in muscle with smaller myofiber area and diameter, which may result in meat with quality problems. Therefore, malnutrition of lambs fed on hay influenced negatively the myofiber morphology and structure. Lambs finished in feedlot on complete diet or on pasture with supplementation did not present any difference regarding muscle and meat quality attributes. 


\section{Literature Cited}

BOEHM, M.L., KENDALL, T.L., THOMPSON, V.F. et al. Changes in the calpains and calpastatin during postmortem storage of bovine muscle. Journal of Animal Science, v.76, p.2415-2434, 1998.

DU, M.; ZHU, M.J.; MEANS, W.J. et al. Effect of nutrients on calpain and calpastatin content of skeletal muscle from cows and fetuses. Jounal of Animal Science, v.82, p.2541-2547, 2004.

GREENWOOD, P.L.; HUNT, A.S.; HERMANSON, J.W. et al. Effect of birth weight and postnatal nutrition on neonatal sheep: II. Sheletal muscle growth and development. Journal of Animal Science, v.78, p.50-61, 2000.

IMMONEN, K.; RUUSUNEN, M.; PUOLANNE, E. Some effects of residual glycogen concentration on the physical and sensory quality of normal pH beef. Meat Science, v.55, n.1, p.33-38, 2000.

KRAUSGRILL, D.J.; TULLOH, N.M.; SHORTHOSE, W.R.; SHARPE, K. Effects of weight loss in ewes in early pregnancy on muscles and meat quality of lamb. Journal of Agricultural Science, v.132, n.2, p.103-166, 1999.

LEFAUCHEUR, L.; GERRARD, P. Muscle fibre plasticity in farm mammals. Proceeding of the Americam Society of Animal Science, 1998. Disponível em: <http://www.jas.fass.org $>$. Acesso em: 10/8/2007.

LEONARDO, E.F.; DELGADO, E.F.; BAGALDO, A.R. et al. Differential growth retardation and Myofibrillar fragmentation in rats submitted to feed restriction and realimentation. Scientia Agricola, v.65, n.2, p.122-129, 2008 .

MACEDO, R.M.G. Características morfologicas e histoquímicas do tecido muscular esquelético de cordeiros Corriedale, puros e mestiços, durante o crescimento, terminados em pastagem ou confinamento. 2000, 120f. Tese (Doutorado em Ciências Biológicas - Zoologia) - Universidade Estadual Paulista, Botucatu, 2000a.
MACEDO, R.M.G.; PAI-SILVA, M,D.; PAI, V.D. et al. Morphology and histochemistry of muscle fiber types of skeletal muscle tissue of lambs during growth. Acta Scientiarum, v.22, n.2, p.581-585, 2000b.

McDONAGH, M.B.; FERNANDEZ, C.; ODDY, V.H. Hind-limb protein metabolism and calpain system activity influence postmortem change in meat quality in lamb. Meat Science, v.52, n.1, p.9-18, 1999 .

McGEEHIN, B.; SHERIDAN, J.J.; BUTLER, F. Factors affecting the $\mathrm{pH}$ decline in lamb after slaughter. Meat Science, v.58, p.79-84, 2001.

MEXIA, A.A.; MACEDO, F.A.F.; MACEDO, R.M. et al. Desempenho e características das fibras musculares esqueléticas de cordeiros nascidos de ovelhas que receberam suplementação alimentar em diferentes períodos da gestação. Revista Brasileira de Zootecnia, v.35, n.4, p.1780-1787, 2006 (supl.).

NATIONAL RESEARCH COUNCIL (NRC). Nutrient Requeriments of sheep. Washington, D.C.: National Academy Press, 1985. 99p.

PETHICK, D.W.; ROWE, J.B. The effect of nutrition and exercise on carcass parameters and the level of glycogen in skeletal muscle of Merino sheep. Australian Journal of Agricultural Research, v.47, n.4, p.525-537, 1996.

STATISTICAL ANALYSIS SYSTEM - SAS. SAS procedures guide. Release 6. 3ed. Cary, 1989. 1686p.

VAN SOEST, P.J. Nutritional Ecology of the ruminant. 2 ed. Ithaca and London: Cornell University Press, 1994. 476p.

VELASCO, S.; CAÑEQUE, V.; LAUZURICA, S. et al. Effect of different feeds on meat quality and fatty acid composition of lambs fattened at pasture. Meat Science, v.66, p.457-465, 2004.

WhipPle, G.; KOOHMARAIE, M.; DiKeMAN, M.E. et al. Predicting beef-longissimus tenderness from various biochemical nd histological muscle traits. Journal of Animal Science, v.68, p.4193-4199, 1990. 